\title{
Study for vitreous waste recovery in the formulation of heavy clay ceramics
}

\begin{abstract}
The study was to analyze the technical feasibility of the incorporation of vitreous waste, from enamel decanters, into a heavy clay mass for fired clay ceramic structural block production. The analyzed waste is considered as class I-Dangerous due to the presence of toxic elements in the leachate above the Brazilian waste classification standard. Six formulations made the standard mass and others with different percentages $(2,5,10$, 15 and $20 \%$ ) of the added waste. Chemical and mineralogical characterization tests of the raw materials carried out. The technological properties evaluated were linear thermal retraction of drying and firing, loss on fire, water absorption and mechanical resistance. The results presented in the formulations demonstrated the feasibility of using up to $20 \%$ by weight in standard mass. Where it was possible to decrease the water absorption and increase the mechanical strength. This work also contributes to the reduction of the environmental impact and favors the sustainable development of the heavy clay ceramics contributing to the improvement of the quality of the pieces.
\end{abstract}

Volume I Issue 2 - 2017

\author{
Jordana Mariot Inocente, ' Vitor de Souza \\ Nandi,' Fábio Rosso,' Alex de Oliveira, ${ }^{2}$ \\ Alexandre Zaccaron ${ }^{3}$ \\ 'Department of Ceramic Engineering, Centro Universitário \\ Barriga Verde, Brazil \\ ${ }^{2}$ Esmalglass-Itaca Group, Brazil \\ ${ }^{3}$ University of Extremo Sul Catarinense, Brazil
}

Correspondence: Jordana Mariot Inocente, Department of Ceramic Engineering, Centro Universitário Barriga Verde, Brazil, Email jordanainocente@hotmail.com

Received: August 07, 2017 | Published: August 24, 2017

Keywords: heavy clay ceramic, waste recovery, vitreous waste, fired clay ceramic structural block

Abbreviations: $\mathrm{SiO}_{2}$, silica; $\mathrm{Al}_{2} \mathrm{O}_{3}$, alumina; $\mathrm{STD}$, standard mass; $\mathrm{Fe}_{2} \mathrm{O}_{3}$, iron oxide; $\mathrm{CaO}$, calcium; $\mathrm{MgO}$, magnesium; $\mathrm{K}_{2} \mathrm{O}$, potassium; FRX, fluorescence spectrometry

\section{Introduction}

Over time, the planet's natural resources, formerly considered abundant, have been used indiscriminately generating significant amounts of solid waste. However, this practice has caused serious environmental problems. The civil construction sector, particularly in the manufacture of inputs, is constantly increasing with great potential impact. ${ }^{1-4}$ Although the construction industry is responsible for relevant environmental demand. It has a major positive impact on society and the economy accounting for $30 \%$ of industrial employment in the European Union (EU) and contributing about 10.4\% to the GDP of the EU. ${ }^{5,6}$ In Brazil, the sector saw a 3\% decline in the national GDP, from $8 \%$ to $5 \%$. The economy already gives indications that will grow again which will improve the construction market. ${ }^{7}$ Solid waste is generated in all manufacturing processes. Therefore, recycling or re-use within the same process can be a reasonable way of preserving the environment. However, increasing the value of by-products using the waste recovery methodology has been a sustainable alternative to avoid their disposal in soil conditioners or landfills. ${ }^{3}$ Industrial ecology is an emerging integrated tool to guide industries to use materials, energy sustainably and reduce waste generation. Such a tool considers industrial wastes as by-products or alternative materials that can feed another industry. ${ }^{8}$

Currently produced ceramic coatings are generally composed of three distinct layers: the ceramic support, the englobe and the enamel. ${ }^{9}$ Which demands a large amount of raw material generating a series of process wastes? Considering the great production of ceramic coatings and their high potential for tailings generation (approximately 10 tons per $100,000 \mathrm{~m}^{2}$ produced). ${ }^{10}$ It becomes essential to study the reuse of waste from the coatings ceramic manufacturing process, more precisely from the enamel preparation or enameling lines.
Ceramic materials are among those most traditionally used in the construction sector. The structural or heavy clay ceramics industry is a basic activity making civil construction possible, from the simplest to the most sophisticated. This segment which mainly produces perforated bricks, solid bricks, slab components, hollow and structural blocks, tiles, shackles and rustic floors. Is very important in generating income in the Brazilian industrial sector. ${ }^{11}$ For masonry, heavy clay ceramic have been an important building material for a long time. The annual global of ceramic for masonry production is currently around 1400billion and its demand is expected to grow steadily. Such a productive increase demands a large amount of raw material which generates environmental problems related to the scarcity of natural resources. ${ }^{12,13}$

Although the sector has a great environmental degrading potential due to mineral extraction by the high consumption of clay. The manufacture of red ceramics is able to absorb high amounts of solid residues from several segments, mainly due to the large volumes involved, allows greater tolerance in the composition of its mass. This factor causes the number of researches to increase the incorporation of a series of residues in ceramic mass, such as glass, ${ }^{14,15}$ ashes of the most diverse sources, ${ }^{16-18}$ mining wastes, ${ }^{19}$ sludge from a wide variety of treatment sources, ${ }^{20-22}$ waste from heavy clay ceramic process ${ }^{23-26}$ and other wastes.

Therefore, innovative approaches to the production of heavy clay ceramics that are less dependent on virgin sources are highly encouraged from the perspective of protecting natural resources and sustainable development. ${ }^{27}$

Within this premise, the study aims to take advantage of a residue from the manufacture of ceramic coating. More specifically the enamel industry as a raw material to incorporated with the manufacture of ceramic blocks for masonry. The waste it is a ceramic sludge, rich in vitreous and fluxing materials that if deposited in inappropriate places cause contamination of the environment. Mainly because it 
contains significant quantities of heavy metals (lead and cadmium) and considerable proportions of aluminum. According Brazilian standard ABNT NBR $10004 / 2004,{ }^{28}$ this waste is considered Class I (dangerous), but when reused properly it can favor the reduction of expenses, contribute to sustainable development and in most cases provides improvement in the final quality in the product.

\section{Materials and methods}

The ceramic residue used in this work provided by a Brazilian company from Santa Catarina state from the process of washing and residues of enamels. The ceramic mass supplied by a ceramic company from South of Santa Catarina, Brazil used for the manufacture of structural blocks. The clay mass was obtained from the mixture of four clays that was collected after complete homogenization and removal after the rolling process. Approximately $50 \mathrm{~kg}$ of mass was collected, which was denominated as Standard Mass (STD). By quarteator the sample was then reduced to $10 \mathrm{~kg}$ for laboratory work, where part of the sample was dried together with the residue in an incubator with a temperature of $70 \pm 5^{\circ} \mathrm{C}$ for $24 \mathrm{~h}$.

After drying, $100 \mathrm{~g}$ of each material placed in $1 \mathrm{~L}$ of water (in separate pots) and kept at rest for $24 \mathrm{~h}$ for maximum saturation to facilitate the performance of the Raw Residue test in a sieve with opening of 325 mesh $(44 \mu \mathrm{m})$.

The ideal moisture for making these specimens is determined by the Pfefferkorn plasticity assay. The plasticity index determined by this method corresponds to the percentage for which the samples has a deformation of $30 \%$ in relation to its initial size $(40 \mathrm{~mm})$. Being a ratio of the initial measure to the final. To determine the ideal extrusion humidity of the formulated samples, the plasticity test is performed with the Standard Mass (STD), with the following humidity percentages: $15,18,20,22$, and $24 \%$.

Then part of the sample material was chemically analyzed by means of an X-ray fluorescence spectrometer (XRF, Philips model PW 2400). The waste was classified based on the American methodology SW 846-3050B ${ }^{29}$ and the Brazilian technical references: ABNT NBR 10004/2004 - Solid waste - Classification, ${ }^{28}$ ABNT NBR 10005/2004 - Procedure for obtention leaching extract of solid waste, ${ }^{30}$ ABNT NBR 10006/2004 - Procedure for obtention of solubilized extraction of solid waste ${ }^{31}$ and ABNT NBR 10007/2004 - Sampling of solid waste. $^{32}$ In a later step, six formulations developed varying their percentage as a function of the amount of waste added. Containing percentages of 0 to $20 \%$ by weight of waste to the ceramic mass, as shown in Table 1. For this procedure the weighings of the Standard Mass (STD) and also of the waste were carried out with a balance (electronic mark, model SF-400 with a maximum capacity of $10 \mathrm{~kg}$ ). The amount of sample prepared was $1 \mathrm{~kg}$ for each formulation and then homogenized manually with the help of a metal spatula and then an eccentric mixer. The duly identified formulations were packed in hermetically sealed plastic containers for moisture homogenization for a period longer than $24 \mathrm{~h}$.

The conformation was formulated using a laboratory press with a capacity of 15 tons. Ten samples were pressed for each formulation in a total of 60 samples at a pressure of 5 tons. What is equivalent to $29 \mathrm{KgF} / \mathrm{cm}^{2}$, that is, the pressure exerted by the extrusion process? The samples are press with diameters of $73 \mathrm{~mm}$ and thickness of $15 \mathrm{~mm}$ identified, weighed, and measured. The samples they were then placed in an industrial continuous dryer together with the products produced by the company with an initial temperature of $35 \pm 10^{\circ} \mathrm{C}$ and relative humidity of $\sim 88 \%$ and final mean temperature of $100 \pm 10^{\circ} \mathrm{C}$ and relative humidity of $\sim 13 \%$, in which they remained for $36 \mathrm{~h}$ for partial removal of moisture. This procedure was adopted in order to guarantee the same conditions established by the industrial process.

The already dried samples are sent to industrial continuous furnace burning, together with the products produced daily by the company, with a maximum temperature of $870 \pm 15^{\circ} \mathrm{C}$, with a total cycle of $35 \mathrm{~h}$ and a firing stage of $8 \mathrm{~h}$.

After the burn, the samples were characterized by linear retraction of burning, loss of ignition, mechanical resistance to flexion (diametric compression) in a universal machine of mechanical tests (EMIC model DL 20000) and water absorption.

Table I Percentage composition of the formulations used

\begin{tabular}{lllllll}
\hline Compositions & STD & $\mathbf{F}_{\mathbf{1}}$ & $\mathbf{F}_{\mathbf{2}}$ & $\mathbf{F}_{\mathbf{3}}$ & $\mathbf{F}_{\mathbf{4}}$ & $\mathbf{F}_{\mathbf{5}}$ \\
\hline Standard mass (\%) & 100 & 98 & 95 & 90 & 85 & 80 \\
Waste (\%) & 0 & 2 & 5 & 10 & 15 & 20
\end{tabular}

\section{Results and discussion}

Table 2 shows the chemical composition of the raw materials obtained by X-ray fluorescence spectrometry (FRX), where it is possible to verify the predominance of silica $\left(\mathrm{SiO}_{2}\right)$ and alumina $\left(\mathrm{Al}_{2} \mathrm{O}_{3}\right)$ in all samples. Silica is found in several mineralogical phases, clayey and non-clayey, especially quartz (its purest natural form) and kaolinite $\left(\mathrm{Al}_{2}\left(\mathrm{Si}_{2} \mathrm{O}_{5}\right)(\mathrm{OH})_{4}\right)$. Alumina is also generally associated with kaolinite, being a very characteristic mineralogical phase of clays. ${ }^{33}$ At lower levels, iron oxide $\left(\mathrm{Fe}_{2} \mathrm{O}_{3}\right)(0.46 \%$ in the waste and $6.22 \%$ in the STD) is also present in all feed stocks and sodium oxide and potassium $\left(\mathrm{Na}_{2} \mathrm{O}\right.$ e $\left.\mathrm{K}_{2} \mathrm{O}\right)$, varying between 1 at $3 \%$ respectively. Iron oxide is known to favor reddish tones in the burned parts and by the fluxing effect in the ceramics. Potassium and sodium oxide also has a fluxing effect on the mass, forming eutectics and reducing the sintering temperature, contributing to the densification of the material at temperatures below $1100^{\circ} \mathrm{C} .{ }^{34}$

It can be observed that the waste presents significant levels of alkaline earth metals, mainly calcium oxide this also contributes to assist the sintering of the ceramic mass in certain temperatures. The presence of calcium $(\mathrm{CaO})$, magnesium $(\mathrm{MgO})$ and potassium $\left(\mathrm{K}_{2} \mathrm{O}\right)$ assist with increasing resistance to sudden changes in temperature. The presence of silica $\left(\mathrm{SiO}_{2}\right)$ in main content is an indicator that the residue can improve the quality of the piece, mainly in the mechanical strength, since it is an oxide flux related to the verification of the material. ${ }^{35}$

In the waste classification test, it was observed physical-chemical characteristics such as in natural humidity at $105^{\circ} \mathrm{C}$ of $38.76 \%$, a density of $1.54 \mathrm{~g} / \mathrm{cm}^{3}$ and suspended solids of $86.61 \%$.

The results also indicated that the residue is not flammable. In a mixture with water in a ratio of $1: 1$ by weight, it has a $\mathrm{pH}$ of 9.4 , not exceeding the limit established by the Brazilian standard ABNT NBR 10004/2004, ${ }^{28}$ letter "a" item "4.2.1.2 Corrosively", being "noncorrosive" for this test. For presenting in its constitution sulfide ion in concentration below the limit established by the Brazilian standard ABNT NBR 10004/2004, ${ }^{28}$ letter "d" item "4.2.1.3 Reactivity", being "non-reactive" for this test. Table 3 shows the parameters tested for toxicity in the leaching test. 
Table 2 X-ray fluorescence of raw materials (\%)

\begin{tabular}{lllllllllllll}
\hline Oxide & $\mathrm{Al}_{2} \mathrm{O}_{3}$ & $\mathrm{SiO}_{2}$ & $\mathrm{CaO}$ & $\mathrm{Fe}_{2} \mathbf{O}_{3}$ & $\mathrm{~K}_{2} \mathbf{O}$ & $\mathbf{M g O}$ & $\mathrm{MnO}$ & $\mathrm{Na}_{2} \mathbf{O}_{2}$ & $\mathbf{P}_{2} \mathbf{O}_{5}$ & $\mathrm{TiO}_{2}$ & $\mathrm{ZrO}$ & $\mathrm{ZnO}$ \\
\hline Mass & 17.06 & 65.20 & 0.19 & 6.22 & 2.97 & 1.17 & 0.01 & 1.13 & 0.12 & 0.87 & - & - \\
Waste & 13.85 & 52.34 & 7.41 & 0.46 & 2.68 & 2.02 & - & 1.30 & 0.06 & 0.14 & 3.45 & 4.80 \\
\hline
\end{tabular}

Table 3 Results obtained for the leaching test

\begin{tabular}{|c|c|c|c|c|}
\hline Parameters & Unit & Results & $\begin{array}{l}\text { Leachable } \\
\text { maximum limit }\end{array}$ & LQ \\
\hline Arsenic & $(\mathrm{mg} / \mathrm{L})$ & 0.002 & 1.0 & 0.001 \\
\hline Barium & (mg/L) & 100 & 70 & 0.1 \\
\hline Cadmium & $(\mathrm{mg} / \mathrm{L})$ & ND & 0.5 & 0.01 \\
\hline Lead & $(\mathrm{mg} / \mathrm{L})$ & 4.70 & 1.0 & 0.01 \\
\hline Total chromium & $(\mathrm{mg} / \mathrm{L})$ & 0.05 & 5 & 0.02 \\
\hline Fluoride & $(\mathrm{mg} / \mathrm{L})$ & 0.2 & 150 & 0.1 \\
\hline Mercury & $(\mathrm{mg} / \mathrm{L})$ & ND & 0.1 & 0.002 \\
\hline Silver & $(\mathrm{mg} / \mathrm{L})$ & ND & 5 & 0.01 \\
\hline Selenium & $(\mathrm{mg} / \mathrm{L})$ & 0.002 & 1 & 0.002 \\
\hline $\begin{array}{l}\text { Dry solids } \\
\text { content }\end{array}$ & $(\%)$ & 61.24 & NA & 0.01 \\
\hline Initial $\mathrm{pH}$ & NA & 9 & NA & 0.1 \\
\hline Final pH & NA & 5.8 & NA & 0.1 \\
\hline Leaching time & hour & 18 & \pm 2 & NA \\
\hline $\begin{array}{l}\text { Volume of } \\
\text { leaching }\end{array}$ & $\mathrm{mL}$ & 500 & NA & NA \\
\hline
\end{tabular}

Due to the results obtained during the leaching test, the residue is toxic because it contains barium and lead in concentrations. Higher than the values listed in Annex F, letter "a" of the item "4.2.1.4 Toxicity" by the Brazilian standard ABNT NBR 10004/200428 being classified as Class I - Dangerous. LQ=Limit of quantification; $\mathrm{ND}=$ Not detected; $\mathrm{NA}=$ Not applicable.

Table 4 presents the results of the Raw Residue of the STD and enamel waste, showing that the residue used has a smaller particle size than the standard mass, directly aiding in the packaging factor, contributing to a better compaction.

The results expressed in Figure 1 indicate that samples containing approximately $22.5 \%$ moisture had the best condition. This content is the standard for the accomplishment of the conformation of the specimens.

Table 4 Percentage of raw residue retained in 325 mesh sieve

\begin{tabular}{|c|c|}
\hline \multicolumn{2}{|c|}{ Raw residue $325 \#(\%)$} \\
\hline STD & 27,3 \\
\hline Waste & 38,4 \\
\hline
\end{tabular}

The graph of Figure 2 shows the results of total linear thermal retraction (drying and firing) of the formulations and standard mass (STD) used in the study. It is possible to observe that in the linear retraction of drying the results decrease with the increase of the added waste. The burning tends to reduce the amount of organic material present in the clays and its dimensions too. Therefore, it is possible to analyze the difference in the linear retraction of burning of the formulations. As the waste content increases it also increased retraction, because of the waste having considerable amounts of fluxing materials as shown in Table 2, which aids in the fusion of the piece, causing the retraction.

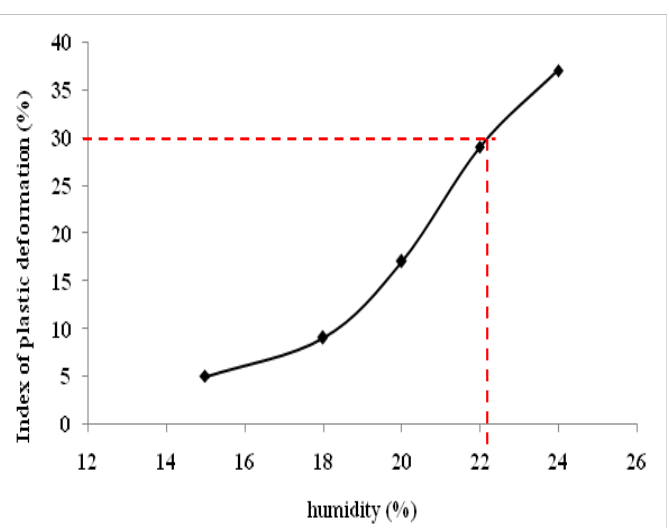

Figure I Index of plastic deformation by the humidity of the plasticity test by Pfefferkorn test.

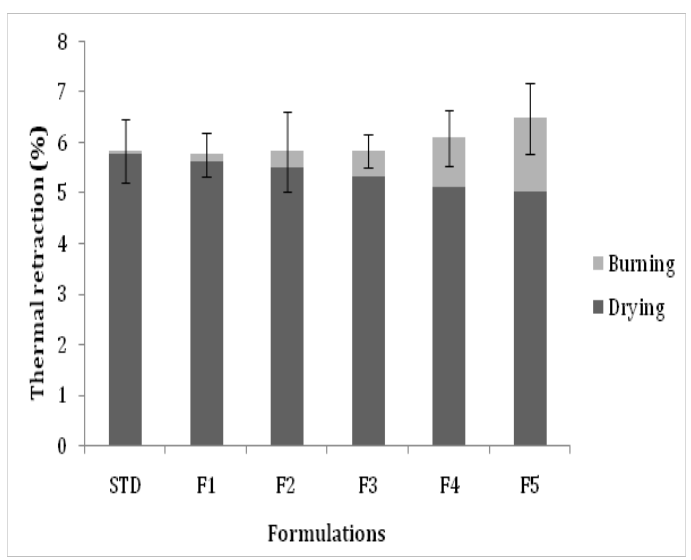

Figure $\mathbf{2}$ Linear thermal retraction of the formulations studied.

According to Figure 3, the loss of ignition of the standard mass and of the formulations was coherent, since they presented values between 5.5 at $7 \%$, indicating to be relatively poor in organic matter. The results also indicate a reduction in loss of ignition as the residual content increases, since the residue presents a lower amount of organic matter $(4.81 \%)$ than the standard mass $(7.39 \%)$.

The results of mechanical strength obtained by the diametrical compression method and the water absorption presented in the graph (Figure 4). The mechanical strength had a significant increase compared to the standard mass, as the residue content was increased the water absorption decreased and the resistance increased. Formulations F5 and F6 showed higher strength (5.8MPa) and lower absorption for F5 $(\sim 14 \%)$ and F6 $(\sim 12 \%)$. Again, these results are related to the considerable content of fluxes in the waste. This favors 
the formation of liquid phase in the sintering process. Reducing the amount of pores favoring the reduction of water absorption and the increases of the mechanical resistance. Which for companies this is of fundamentally important because it guarantees the quality of the final product.

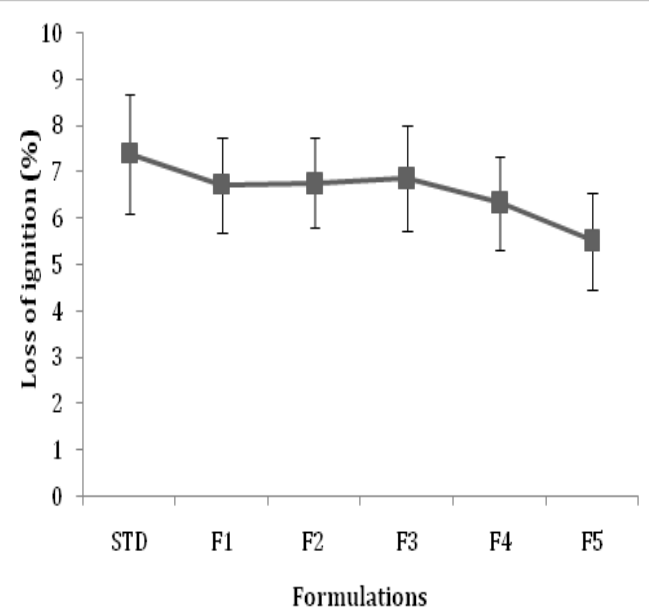

Figure 3 Loss of ignition of the standard mass and formulations used in this research.

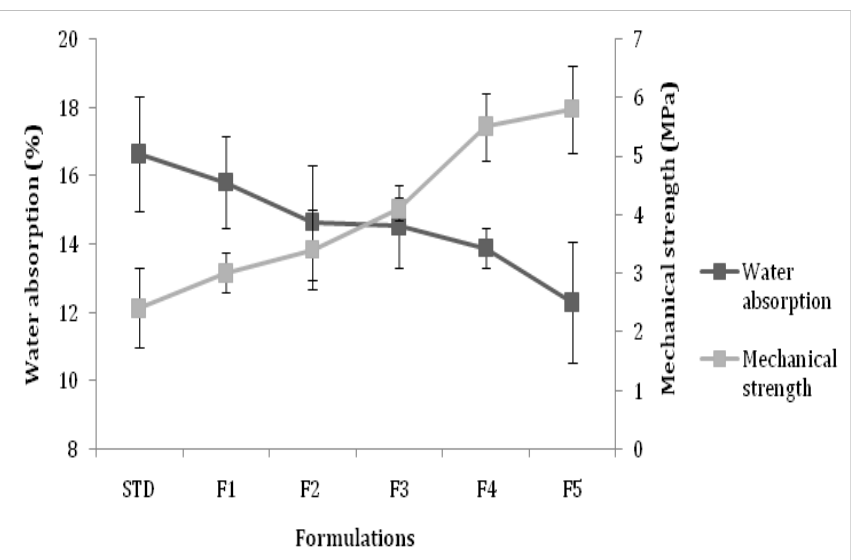

Figure 4 Water absorption versus mechanical resistance to diametric compression of the formulations carried out in the research.

\section{Conclusion}

Through the work carried out, it can be said that the addition of the enamel waste to the clayey mass of heavy clay ceramics influences its properties. Changing its characteristics in the finished product. It is a flux waste the silica base when sintered forms a liquid phase, decreases the porosity of the material, and causing a sintering faster or at a lower temperature. Additions from enamel waste contributed to the increase of physical properties such as burning retraction, mechanical resistance to bending, and decreased water absorption and loss of ignition. The higher the addition the more intense this effect. These tailings have the potential to be used as an alternative raw material in the manufacture of heavy clay ceramics and therefore, from a manufacturing point of view, can be used as a great flux that still generates improvements in the characterization of the final product and gains in sustainable marketing. With this waste it can possible of introducing faster firing cycles.

\section{Acknowledgements}

None.

\section{Conflict of interest}

The author declares no conflict of interest.

\section{References}

1. Taurino R, Barbieri L, Bondioli F. Surface properties of new green building material after $\mathrm{TiO} 2-\mathrm{SiO} 2$ coatings deposition. Ceramics International. 2015;42:4866-4874.

2. Domínguez A, Domínguez MI, Ivanova S, et al. Recycling of construction and demolition waste generated by building infrastructure for the production of glassy materials. Ceramics International. 2016;42:1521715223.

3. Nandi VS, Raupp-Pereira F, Montedo ORK, et al. The use of ceramic sludge and recycled glass to obtain engobes for manufacturing ceramic tiles. Journal of Cleaner Production. 2015;86:461-470.

4. Ji R, Wu S, Yan C, et al. Preparation and Characterization of the Onepiece Wall Ceramic Board by Using Solid Wastes. Ceramics International. 2017;43(12):8564-8571.

5. European Commission. Energy-efficient buildings PPP, multi-annual road map and longer term strategy. Belgium: Publications Office of the European Union; 2010.

6. Almeida MI, Dias AC, Demertzi M, et al. Environmental profile of ceramic tiles and their potential for improvement. J Clean Prod. 2016;131:583-893.

7. CBIC-Câmara Brasileira da Indústria da Construção. Banco de Dados 2017.

8. Taha Y, Benzaazoua M, Hakkou R, et al. Coal mine wastes recycling for coal recovery and eco-friendly bricks production. Minerals Engineering. 2016;107:123-138.

9. Dal Bó M, Melchiades FG, Boschi AO, et al. Efeito das propriedades dos esmaltes e engobes sobre a curvatura de revestimentos cerâmicos. Cerâmica. 2012;58:118-125.

10. de S Nandi V, Feltrin J, Volpato M, et al. Caracterização de Resíduo Sólido de ETE da Indústria Cerâmica de Revestimento. Cerâmica Industrial. 2012;17:32-35.

11. Pérez CAS, Paduani C, Ardisson JD, et al. Caracterização de Massas Cerâmicas Utilizadas na Indústria de Cerâmica Vermelha em São Domingos do Sul - RS. Cerâmica Ind. 2010;15:38-43.

12. Zhang L. Production of bricks from waste materials-A review Constr. Build Mater. 2013;47:643-655.

13. Sutcu M, Alptekin H, Erdogmus E, et al. Characteristics of fired clay bricks with waste marble powder addition as building materials. Constr Build Mater. 2015;82:1-8.

14. Phonphuak N, Kanyakam S, Chindaprasirt P. Utilization of waste glass to enhance physical-mechanical properties of fired clay brick. $J$ Clean Prod. 2016;112:3057-3062.

15. Vieira CMF, Morais ASC, Monteiro SN, et al. Teste industrial de cerâmica vermelha incorporada com resíduo de vidro de lâmpada fluorescente. Cerâmica. 2016;62:376-385.

16. Coutinho NC, Vieira CMF. Caracterização e incorporação de cinza de resíduo sólido urbano em cerâmica vermelha. Cerâmica. 2016;62:249255 . 
17. Leiva C, Arenas C, Alonso-fariñas B, et al. Characteristics of fired bricks with co-combustion fly ashes. J Build Eng. 2016;5:114-118.

18. Medeiros de ENM, Sposto RM, De A Neves G, et al. Incorporação de cinza de lenha, lodo de estação de tratamento de água e cinza de casca de arroz em massa cerâmica. Utilização da técnica de planejamento. $\mathrm{Ce}$ râmica. 2010;56 399-404.

19. Taha Y, Benzaazoua M, Hakkou R, et al. Natural clay substitution by calamine processing wastes to manufacture fired bricks. J Clean Prod. 2016;135:847-858.

20. Almeida PHS, Tavares CRG. Influência do tipo de argila no processo de solidificação / estabilização de lodo têxtil. Cerâmica. 2015;61:137-144.

21. Tantawy MA, Sa R. Applied Clay Science Middle Eocene clay from Goset Abu Khashier:Geological assessment and utilization with drinking water treatment sludge in brick manufacture. Appl Clay Sci. 2017; 138:114-124.

22. Coletti C, Maritan L, Cultrone G, et al. Use of industrial ceramic sludge in brick production :Effect on aesthetic quality and physical properties. Constr Build Mater. 2016;124:219-227.

23. Morais MDP De, Macedo RS, Raposo CMO. Preparação e caracterização de sistemas chamote/argila visando o reaproveitamento de descartes industriais. Cerâmica. 2015;61:206-212.

24. Rajamannan B, Viruthagiri G, Jawahar KS. Effect of grog addition on the technological properties of ceramic. Int J Latest Res Sci Technol. 2013;2:81-84

25. Gouveia FP, Sposto RM. Incorporação de chamote em massa cerâmica para a produção de blocos . Um estudo das propriedades físico-mecânicas. Cerâmica. 2009;55:415-419.
26. Zaccaron A, Galatto SL, De S, et al. Incorporação de Chamote na Massa de Cerâmica Vermelha como Valorização do Resíduo. Cerâmica Ind. 2014;19:33-39.

27. Ukwatta A, Mohajerani A. Characterisation of fired-clay bricks incorporating biosolids and the effect of heating rate on properties of bricks. Constrution and Build Materials. 2017;142:11-22.

28. http://www.unaerp.br/documentos/2234-abnt-nbr-10004/file

29. Test Method For Evaluating Solid Waste Report Number SW-846. US EPA-United States Environmental Protection Agency SW 846. USA; 1986.

30. http://wp.ufpel.edu.br/residuos/files/2014/04/ABNT-NBR-10005-Lixiviacao-de-Residuos.pdf

31. http://sites.unicentro.br/wp/educacaoambiental/files/2017/04/NBR10006.pdf

32. ABNT, NBR 10007-Amostragem de resíduos sólidos. Assoc Bras Normas Técnicas. 2004. 21 p.

33. Oliveira AA. Ceramic technology. 1a, Croatia: Lara Publishing House; 2011.

34. Menezes RR, De Almeida RR, Santana LNL, et al. Análise da co-utilização do resíduo do beneficiamento do caulim e serragem de granito para produção de blocos e telhas cerâmicos. Cerâmica. 2007;53:192-199.

35. Zaccaron A, Bernardin AM, Rosso F, et al. Utilização de Vidro de Garrafas para Redução da Absorção de Água em Produtos de Cerâmica Vermelha. Cerâmica Ind. 2016;20:35-39. 